\title{
SOFIAS - Software for life-cycle assessment and environmental rating of buildings
}

\author{
SOFIAS - Herramienta para el análisis de ciclo de vida y la calificación \\ ambiental de edificios
}

$\underline{\text { X. Oregi Isasi }}^{(*)}$, J. A. Tenorio ${ }^{(* *)}$, C. Gazulla ${ }^{(* * *)}$, I. Zabalza ${ }^{(* * * *)}$, D. Cambra ${ }^{(* * *)}$, S. O. Leao ${ }^{(* * *)}$, L. Mabe $^{(*)}$, S. Otero $^{(* *)}$, J. Raigosa $^{(* * *)}$

\section{ABSTRACT}

This paper describes the development process of a new software tool, called SOFIAS (Software for a Sustainable Architecture), funded by the Spanish Ministry of Economy and Competitivenes. Following CEN/TC 350 standard on environmental assessment of buildings, the tool aims at assisting building professionals on reducing the life-cycle environmental impact through the design of new buildings and the refurbishment of existing ones. In addition, SOFIAS provides a rating system based on the Life Cycle Assessment (LCA) methodology. This paper explains the innovative aspects of this software, the working methodology and the different type of results that can be obtained using SOFIAS.

Keywords: LCA software; environmental product declaration; database; rating; building.

\section{RESUMEN}

Este artículo describe el proceso de desarrollo de la nueva herramienta informática SOFIAS (Software de Funciones Integradas para una Arquitectura Sostenible), financiado por el Ministerio de Economóa y Competitividad del Gobierno de España. En base al estandar de la evaluación ambiental de los edificios definido por el CEN/TC 35o, esta nueva herramienta tiene como objetivo ayudar a los técnicos de la construcción en reducir el impacto ambiental durante el ciclo de vida a través del diseño optimizado de nuevos edificios o edificios rehabilitados. De forma paralela, SOFIAS proporciona un nuevo sistema de calificación basado en la metodología del Análisis de Ciclo de Vida (ACV). Este artículo expone los aspectos innovadores de esta herramienta informática, la metodología de trabajo y los diferentes tipos de resultados que se pueden obtener tras su aplicación.

Palabras clave: Software ACV; declaración ambiental de producto; base de datos, calificación; edificios.

${ }^{(*)}$ Tecnalia Research \& Innovation, Energy and Environment Division, Azpeitia, Spain.

${ }^{(* *)}$ CSIC. Eduardo Torroja, Institute for construction Science, Madrid, Spain.

${ }^{(* * *)}$ UNESCO Chair in Life Cycle and Climate Change (ESCI- Pompeu Fabra University), Barcelona, Spain.

${ }^{(* * * *)}$ CIRCE Research Centre for Energy Resources and Consumption, Energy Efficiency Area, Zaragoza, Spain.

Persona de contacto/Corresponding author: xabat.oregi@tecnalia.com (X. Oregi Isasi)

Cómo citar este artículo/Citation: Oregi Isasi, X., Tenorio, J. A., Gazulla, C., Zabalza, I., Cambra, D., Leao, S. O., Mabe, L., Otero, S., Raigosa, J. (2016). SOFIAS - Software for life-cycle assessment and environmental rating of buildings. Informes de la Construcción, 68(542): e151, doi: http://dx.doi.org/10.3989/ic.15.055.

Licencia / License: Salvo indicación contraria, todos los contenidos de la edición electrónica de Informes de la Construcción se distribuyen bajo una licencia de uso y distribución Creative Commons Attribution License (CC BY) Spain 3.o. 


\section{INTRODUCTION}

According to the European Commission Communication on Resource Efficiency Opportunities in the Building Sector (1) the LCA methodology is currently the best framework available to assess the potential environmental impacts of any activity, product or service without geographical, functional or time limits, since it quantifies the environmental impact of the inputs and outputs along its whole life cycle, including the extraction of raw materials, production process, use and end of life stages.

LCA is standardized by ISO 14040 (2) and 14044 (3) standards, and consists of four phases. The first phase is to define the goal and scope of the assessment, which serves as a description of the type of study. The scope of the study determines which processes should be included in the inventory phase of the assessment.In the second phase, the Life $\mathrm{Cy}$ cle Inventory (LCI) includes information on all of the environmental inputs and outputs associated with a product or service. In the third impact assessment phase, the potential contribution of each substance to predefined environmental impact categories is calculated. Once the environmental impact has been calculated, the final step of the assessment is to summarize and discuss the results of the calculations in the interpretation phase. LCA can choose from several methods to quantify the environmental performance of a product, system or process. For example, the CML method (Centrum voor Milieukunde Leiden) (4) uses indicators at midpoint level showing direct potential impact on the environment situated halfway along the chain of causes and effects. On the other hand, the Eco-indicator method (5) includes endpoint indicators, which represent the ultimate consequences of the environmental impact for humans and ecosystems. Specifically for the construction sector, new standards such as EN 15978:2011 (6) already define the different phases of a building life cycle and a number of indicators and methods used to declare the results of the analysis.

Despite the intense standardization work undertook by the European Committee for Standardization (CEN), and spe- cifically by its Technical Committee TC/350 (7), currently the quantitative assessment of the environmental impacts of buildings along their complete life cycle is still seldomly applied by building professionals. In general, architects and building engineer's lack of the time and skills required to use Life Cycle Assessment (LCA) software tools such as Simapro (8), GaBi (9) or Umberto (10). In addition, in order to assess the environmental impact of a building with life cycle approach, different tools have been developed in recent years (see Table 1).

Although the application of the LCA methodology is considerably defined and standardized, the evaluation of the environmental performance of the building's whole life cycle is still not a common practice. Table 1 shows that very few tools and authors considered all the LCA phases in their studies, being a general trend the omission of some life cycle modules such as on site processes (A5) or maintenance (B2) due mainly to the lack of environmental information, the difficulty of predicting future scenarios and the relatively low energy consumption in comparison to the whole life cycle energy demand which according to previous studies (31) is less than $1 \%$.

Along with the problem of the complexity of this type of tools and the problem of the uncertainty regarding the different evaluation scopes applied by each scientif study, one of the main reasons for the development of this software was focused on providing a solution to the fact that the current Spanish energy certification tool, Lider-Calener (32), only quantifies the environmental impacts associated with the use stage of the building. When full life cycle impacts of a building need to be assessed, a second and completely independent study is required which increases efforts and costs.

This paper describes the development of an experimental prototype tool to meet the different needs of professionals regarding full life cycle assessment of buildings, such as:

- Need for evaluation of environmental aspects considering the full life cycle. It is important that professionals can have

Table 1. Evaluation scope of some building LCA software tools and scientific studies that may be used in the building sector.

\begin{tabular}{|c|c|c|c|c|c|c|c|c|c|c|c|c|c|c|c|c|c|c|c|c|}
\hline & \multicolumn{10}{|c|}{ Building LCA software Tools } & \multicolumn{10}{|c|}{ Building LCA scientific studies } \\
\hline & 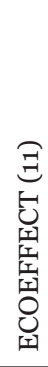 & 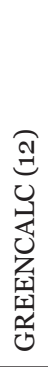 & 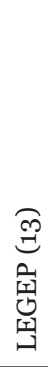 & 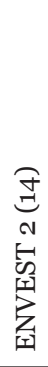 & 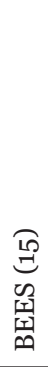 & 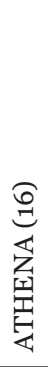 & 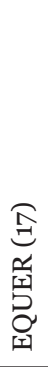 & 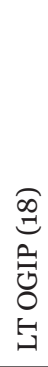 & 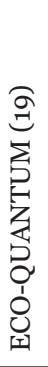 & 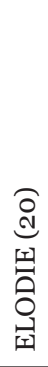 & 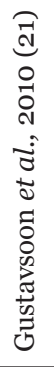 & 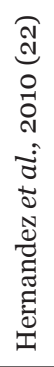 & 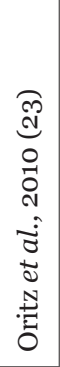 & 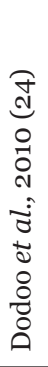 & 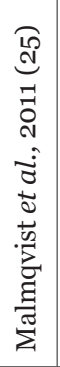 & 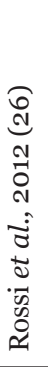 & 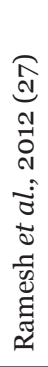 & 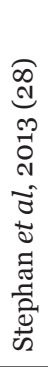 & 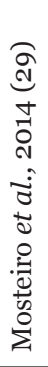 & 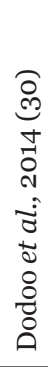 \\
\hline Production (A1-3) & $\mathrm{X}$ & $\mathrm{X}$ & $\mathrm{X}$ & $\mathrm{X}$ & $\mathrm{X}$ & $\mathrm{X}$ & $\mathrm{X}$ & $\mathrm{X}$ & $\mathrm{X}$ & $\mathrm{X}$ & $\mathrm{X}$ & $\mathrm{X}$ & $\mathrm{X}$ & $\mathrm{X}$ & $\mathrm{X}$ & $\mathrm{X}$ & $\mathrm{X}$ & $\mathrm{X}$ & $\mathrm{X}$ & $\mathrm{X}$ \\
\hline Transport (A4) & & & $\mathrm{X}$ & $\mathrm{X}$ & $\mathrm{X}$ & $\mathrm{X}$ & $\mathrm{X}$ & $\mathrm{X}$ & & & $\mathrm{X}$ & & $\mathrm{X}$ & $\mathrm{X}$ & & $\mathrm{X}$ & $\mathrm{X}$ & $\mathrm{X}$ & $\mathrm{X}$ & \\
\hline On site processes (A5) & & & $\mathrm{X}$ & $\mathrm{X}$ & $\mathrm{X}$ & $\mathrm{X}$ & $\mathrm{X}$ & $\mathrm{X}$ & & & & & $\mathrm{X}$ & & & & $\mathrm{X}$ & $\mathrm{X}$ & $\mathrm{X}$ & $\mathrm{X}$ \\
\hline Maintenance (B2) & & & & & & & & & & & & & $\mathrm{X}$ & & & & & & & \\
\hline Replacement (B4) & & & $\mathrm{X}$ & $\mathrm{X}$ & $\mathrm{X}$ & $\mathrm{X}$ & & $\mathrm{X}$ & & & & $\mathrm{X}$ & & & & & $\mathrm{X}$ & $\mathrm{X}$ & $\mathrm{X}$ & \\
\hline Operational energy use (B6) & $\mathrm{X}$ & $\mathrm{X}$ & $\mathrm{X}$ & $\mathrm{X}$ & $\mathrm{X}$ & $\mathrm{X}$ & $\mathrm{X}$ & $\mathrm{X}$ & $\mathrm{X}$ & $\mathrm{X}$ & $\mathrm{X}$ & $\mathrm{X}$ & $\mathrm{X}$ & $\mathrm{X}$ & $\mathrm{X}$ & $\mathrm{X}$ & $\mathrm{X}$ & $\mathrm{X}$ & $\mathrm{X}$ & $\mathrm{X}$ \\
\hline End of life (C1-4) & & $\mathrm{X}$ & $\mathrm{X}$ & $\mathrm{X}$ & $\mathrm{X}$ & $\mathrm{X}$ & $\mathrm{X}$ & $\mathrm{X}$ & $\mathrm{X}$ & & & & $\mathrm{X}$ & $\mathrm{X}$ & & & & & $\mathrm{X}$ & $\mathrm{X}$ \\
\hline
\end{tabular}


this new environmental vision from the beginning of the design process. Need of reference values to allow definition and evaluation of the environmental performance of the building during the different stages of life cycle.

- Need of free quantitative environmental data of materials and processes related to the Spanish construction sector. Currently, the professionals have the possibility to get this kind of information from Environmental Product Declarations (EPD), from some regionals free data base such as Ökobau (33) or from comercial Life Cycle Inventory databases. However, difficulty to access and interpret this information means that in many cases the user dismisses the option to continue their work.

- Need to perform environmental calculation of all building stages and obtain the Environmental Building Declaration (EBD) with very little work and without duplicating the work done for obligatory energy rating.

- Need to communicate and make inteligible these studies and developments to all parties involved.

\section{METHODOLOGY OF SOFIAS}

SOFIAS is based on an algorithm to implement the calculation logic of the LCA methodology of buildings (structured according to life cycle stages and modules defined by EN 15978 (6)).The tool has four mainparts.

\subsection{Project description}

General information of the building project to be analysed, i.e. Type of Project (new construction / renovation) and development phase or level (design / project / after project). The data to be defined by the users vary depending on the characteristics of the project to be analysed, being the "design level" the more simplified scope.

\subsection{Definition of the building life cycle}

Once the general information is provided, the user defines all the inputs used (type and quantity) in the product, construction, use and end-of-life stages. Within the Product Stage, the constructive solutions (facade, roof, internal partitions, walls in contact with the ground and windows), structural elements (foundations and pillars) and (energy generation) installations (renewable and non renewable) are defined through the selection of the constructive solutions or products available in the SOFIAS database, the definition of new objects or by importing pre-existing Lider-Calener (xml) files if available for the project being assessed. Through the communication between the "xml" file generated by Lider-Calener and SOFI$\mathrm{AS}$, the user automatically could import information related to the project, the type of building, floor area, heated area, products thickness, energy consumption and constructive solutions. Within the Construction Stage, the environmental impact of the transport of products to the construction site and the construction process (including earthworks) are assessed. In that stage, users may modify the default data provided by SOFIAS and which are representative for Spain (e.g. energy and water consumption as well as construction waste generated per $\mathrm{m}^{2}$ ) if more specific data are available. In the Use Stage, both the energy consumption and the use of products for replacing materials surpassing their service life are considered. Users are required to introduce the operational energy consumption of the building, which can be calculated with simulation tools (Design and Project Levels) or calcu- lated through real bills in the case of existing buildings (After Project Level). Finally, within the End of Life Stage the environmental impact of the transportation and waste management of the different waste construction flows is calculated. To this end, default scenarios representative for Spain may be adopted or changed if more specific data are available.

\subsection{Database}

To carry out a LCA study of a building requires the collection of a huge amount of quantitative data related to individual products and processes in the different life-cycle stages. As to count on a number of manufacturers to provide reliable firsthand inventory data is a long-term activity, a complementary strategy is the development of a Life Cycle Impact Assessment (LCIA) database with available EPD of construction products (34). Existing EPD programs tackling construction products have been evaluated as potential data sources for feeding SOFIAS database. However, it has to be noted that these programs differ in methodological aspects such as the validity period applied to their EPDs and the verification process, and even more important, the specific calculation rules (or Product Category Rules, PCR) applied to similar products. In order to guarantee the coherence of the EPD data originated in different programs as much as possible, two main aspects were observed. First, the program had to provide EPD independently verified by third-party to be sure that the EPD followed the corresponding PCR. The second aspect observed was the use of similar impact assessment methodology for calculating the following environmental impact results. Up to 366 real EPDs have been finally selected and included in SOFIAS database and, in addition, 165 average data for generic products have been calculated based on existing EPDs as well as LCA datasets.

The database contains quantitative impact information both for the product and the constructive solution. Then, for the evaluation of the production stage and end-of-life stage of the building, calculations are made using the information at the product level, whereas for the construction and use stages, the data refer to the constructive solutions level. For each constructive solution a reference value for their environmental impact is provided which nevertheless may be modified by the user if more accurate data are available.

The classification of the constructive solutions follows the structure of the commonly used Spanish Catalog of Constructive Elements (35) (CEC standing from Catálogo de Elementos Constructivos) also applied in the OpenDAP (database to consult and/or introduce EPD or environmental information about construction products) database developed by the Instituto Eduardo Torroja (36). The "Reference Constructive Solutions" are grouped into families of facades, roofs, horizontal interior partitions, vertical interior partitions, dividing walls and walls in contact with the ground. For each constructive solution the composition in layers, their thicknesses and densities are explained in detail. Up to 67 references constructive solutions are included in the database which may be used or modified by the user to define the building.

\subsection{Calculation of results and rating}

After entering the required data in each section, the overall LCA results can be calculated for the following impact categories: Global Warming (GWP), Ozone Depletion (ODP), 
Acidification for soil and water (AP), Eutrophication (EP), Photochemical Ozone Creation (POCP), Depletion of Abiotic Resources - elements (ADP elements), Depletion of Abiotic Resources - fossil fuels (ADP fossil fuels) and Resource use (total Primary Energy total - PE and Non Renewable Primary Energy - NRPE). SOFIAS offers the possibility of rating the project against a benchmark based on the carbon footprint of a reference building at each life cycle stage. The rating methodology developed by the SOFIAS consortium implies a quantitative assessment of the building's carbon footprint from a linear equation " $\mathrm{y}=\mathrm{mx}+\mathrm{b}$ " generated for each life $\mathrm{cy}-$ cle stage of the building analysed. As shown in Figure 1, the equation is generated by means of two points:

- Point with the highest qualification (10 points on the ordinate axis) corresponds to a life cycle zero-emissions building, which is a theoretical building with no emissions (value o on abscissa) in its whole life cycle. Although the life cycle carbons minus buildings are possible, they are still in the demonstration phase, so they cannot be considered as "best practice" at present.

- Point with the reference qualification (4 points on the ordinate axis) corresponds to a "reference building" complying strictly with the current Spanish Technical Building Code (37) and considering the options with higher equivalent $\mathrm{CO}_{2}$ emissions for each life cycle stage. This means that some existing buildings that do not comply with the current normative can have a qualification below 4 .

To obtain the rating of the building analysed, the tool generates a reference building for each life cycle stage, which provides the value of the equivalent emissions corresponding to a score of 4 points.

In the production stage, the tool generates a different reference equivalent $\mathrm{CO}_{2}$ emissions value for each enclosure of the thermal envelope. The reference building has exactly the same geometry, but its constructive solutions meet the minimum standards set out in the Spanish Building Technical Code.

In the construction processes stage, the tool generates a reference value considering the following criteria. For transportation of the building components, a road transport system by conventional truck is established for all the building products, considering an average distance of $300 \mathrm{~km}$. For the on- site construction processes, the energy consumption of machinery is based on scientific literature (38). Finally in order to set a reference value for the waste generation and management system, road transportation by truck from the building site to a landfill and typical values of waste generation which strictly complies with current regulations are assumed.

In the use stage, the operational emissions of the building analysed can be calculated using the Lider-Calener software, which is the Spanish official tool for energy certification (32). The Lider-Calener rating is automatically converted into the numerical rating of the SOFIAS tool according to Table 2.

Finally, in the end of life stage, the tool generates a reference value considering that all building components are transformed into waste at the end of life. Road transportation by truck from the building site to a landfill is assumed, covering a distance of $50 \mathrm{~km}$. The energy consumption for deconstruction processes is based on the scientific literature (38).

Once the references are calculated for the different life cycle stages, a global rating for the building is calculated based on a linear equation. The second point of this line is calculated by adding the equivalent $\mathrm{CO}_{2}$ emissions reference values for each life cycle stage. With the aim of providing a simple visual rating for the users, the SOFIAS numerical rating is converted into a "stars" system score as shown in the table above (see Table 2).

Table 2. Conversion from the energy rating provided by the Lider-Calener tool for the use stage tothe numerical rating considered in the SOFIAS tool and equivalence between numerical andvisual rating in SOFIAS.

\begin{tabular}{|c|c|c|}
\hline $\begin{array}{c}\text { Lider-Calener } \\
\text { Energy Rating }\end{array}$ & $\begin{array}{c}\text { SOFIAS } \\
\text { Numerical Rating }\end{array}$ & $\begin{array}{c}\text { SOFIAS } \\
\text { Visual Rating }\end{array}$ \\
\hline A & 10 points & +++ \\
\hline B & 8.5 points & +++ \\
\hline C & 7 points & ++ \\
\hline D & 5 points & + \\
\hline E & 4 points & NO rating \\
\hline F & 2 points & NO rating \\
\hline G & o points & NO rating \\
\hline
\end{tabular}

\section{Qualification Theoretical Building}

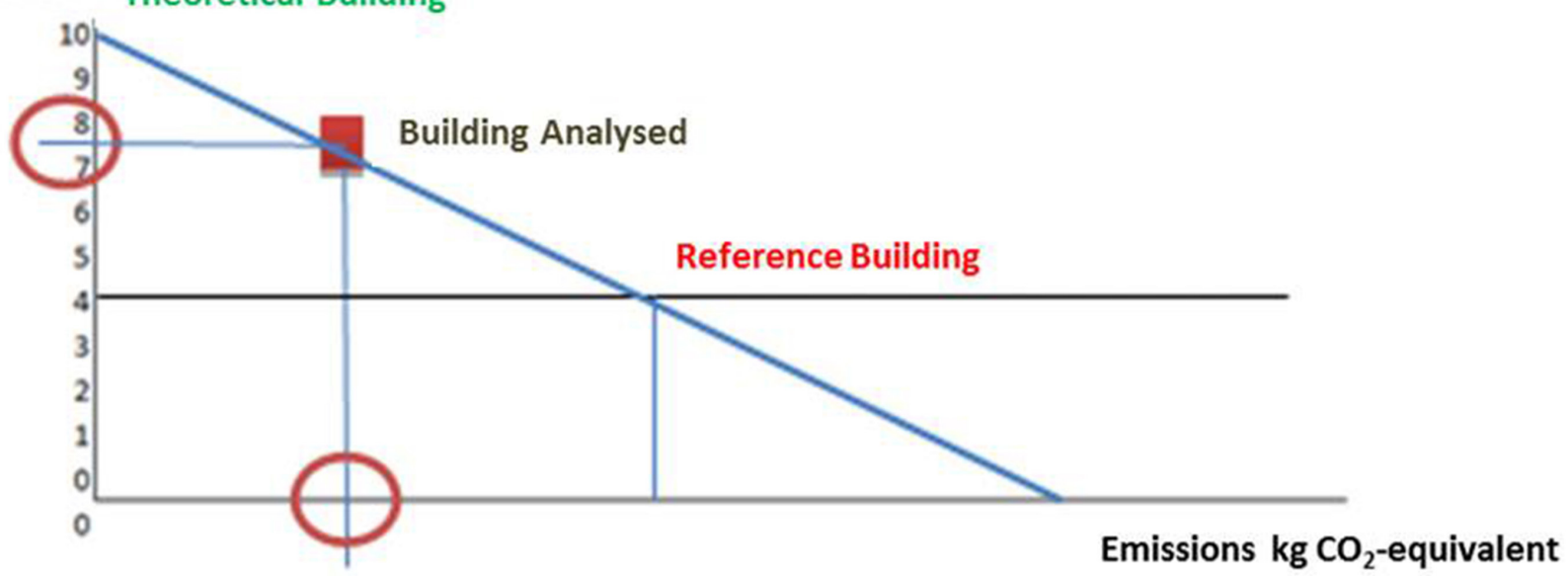

Figure 1. Linear equation (qualification vs carbon footprint) generated by the SOFIAS tool for the building rating in each life cycle stage. 


\section{CASE STUDY}

\subsection{Description of the building}

The case study presented in this paper is a building located in the municipality of Zaragoza (Spain). It is a building that is representative of homes constructed in the last 10 years in Spain, but differs with regard to the choice of materials used for the thermal envelope. This case study (see Figure 2) was selected as a good example of a block apartment building, complying with the Energy Performance of Buildings European Directive requirements and including some bioclimatic and environmental sustainability criteria. Through this case study, the tool allows to assess the reduction of the environmental impact compared to a reference building just meeting the current normative.
The building is a residential block of 60 homes, with a built surface of $8,607 \mathrm{~m}^{2}$ distributed over 5 floors above ground level for homes and 2 underground floors intended for parking with a surface of $3,054 \mathrm{~m}^{2}$.

\subsection{Input data}

\subsubsection{Product stage}

The data to be entered into SOFIAS corresponds to the constructive elements (see Table 3), vertical structure and installations of the building.

The amount of concrete and steel considered in the vertical structure of the building (above ground and garage stories) are 374 and 17 tons respectively.

Table 3. Inventory of building materials of the building enclosure and structure to be entered into the SOFIAS tool.

\begin{tabular}{|c|c|c|c|c|}
\hline Enclosure & Surface $\left(\mathrm{m}^{2}\right)$ & Material Layers & Volume $\left(\mathrm{m}^{3}\right)$ & Density $\left(\mathrm{kg} / \mathrm{m}^{3}\right)$ \\
\hline \multirow{5}{*}{$\begin{array}{l}\text { North, East and West } \\
\text { Facades }\end{array}$} & \multirow{5}{*}{3,272} & Ceramic tile & 65.45 & 2,000 \\
\hline & & Agglomerated cork & 71.43 & 115 \\
\hline & & Lime mortar & 10.86 & 1,125 \\
\hline & & Light clay brick, thickness: $24 \mathrm{~cm}$ & 621.78 & 920 \\
\hline & & Plaster skimming & 32.73 & 900 \\
\hline \multirow{3}{*}{ South Facade } & \multirow{3}{*}{706} & Single layer coating & 4.59 & 1,250 \\
\hline & & Light clay brick, thickness: $24 \mathrm{~cm}$ & 169.62 & 920 \\
\hline & & Plaster skimming & 14.14 & 900 \\
\hline \multirow{3}{*}{ Internal wall } & \multirow{3}{*}{6,371} & Plaster skimming & 509.72 & 900 \\
\hline & & Brick & 892.01 & 630 \\
\hline & & Plaster skimming & 509.72 & 900 \\
\hline \multirow{4}{*}{ Internal foundation } & \multirow{4}{*}{7,290} & Flat ceramic tile & 63.18 & 2,000 \\
\hline & & Cement mortar & 218.70 & 1,250 \\
\hline & & Lightweight reinforced concrete & 583.20 & 1,929 \\
\hline & & Plaster skimming & 145.80 & 900 \\
\hline $\begin{array}{l}\text { Ground foundation / } \\
\text { Grounded wall }\end{array}$ & 1,527 & Reinforced concrete & 229.08 & 1,850 \\
\hline \multirow{4}{*}{ Roof } & \multirow{4}{*}{1,069} & Ceramic roof tile & 65.45 & 2,000 \\
\hline & & Extruded polystyrene & 53.45 & 38 \\
\hline & & Lightweight reinforced concrete & 320.70 & 1,090 \\
\hline & & Plaster skimming & 21.38 & 900 \\
\hline Doors & 806.4 & Inner wooden door & - & 27.60 \\
\hline Windows & $1,817.4$ & Double glazing 5-10-6 & - & 27.50 \\
\hline
\end{tabular}
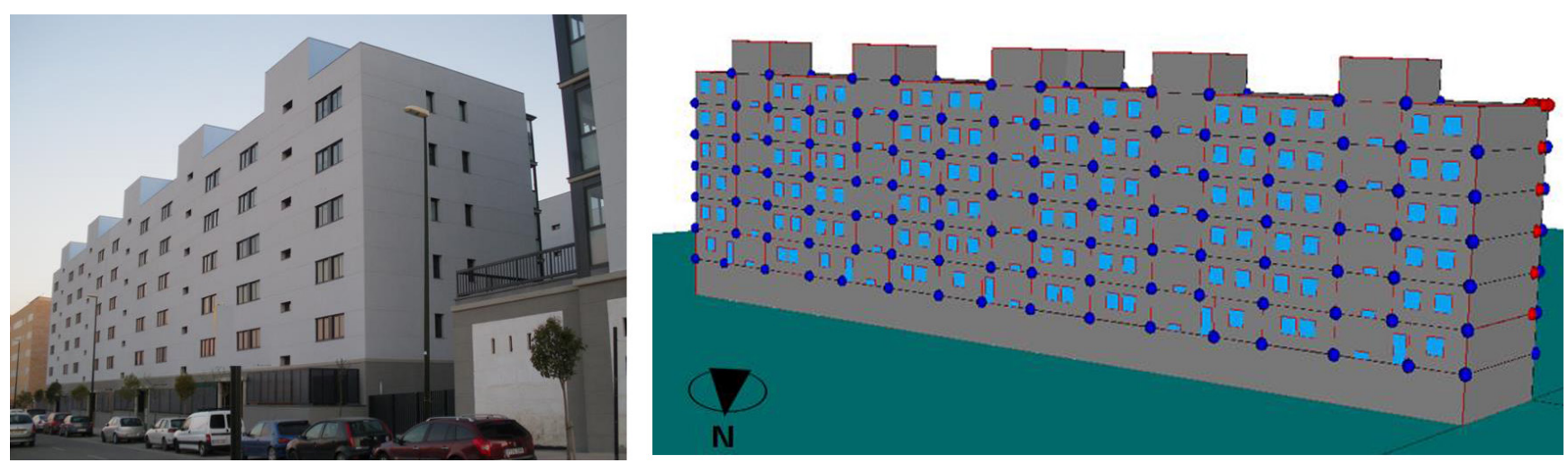

Figure 2. Image of the residential building used as case study and 3D model of the building in the Spanish energy certification tool Lider-Calener. 
Regarding installations, the building incorporates a mixed low temperature boiler running on natural gas, with a nominal power of $450 \mathrm{~kW}$, with a combustion performance of 93.6\% to provide heating and sanitary hot water. It does not currently have an active cooling system. With regard to the renewable generation systems incorporated in the building, in accordance with the regulations, it has 30 flat-panel thermal solar collectors with a total capture surface area of $57 \mathrm{~m}^{2}$, which exclusively provides $50 \%$ of the demand for sanitary hot water.

Figure 3 presents the input data needed for each building constructive solution in the SOFIAS tool (40), including the constructive elements, the vertical structure and the renewable generation equipment. Other types and parts of the Heating, Ventilating, and Air Conditioning (HVAC) systems of the building are not considered within the system boundaries. The main reason is that the environmental impact associated to the production of these elements are negligible compared to the impact of the other products and elements within the system boundaries. Thus, it is possible to simplify the analysis, keeping the accuracy of the LCA results.

\subsubsection{Construction process stage}

Table 4 shows the data to be estimated calculating the environmental impact of the construction stage. It is estimated that to construct $1 \mathrm{~m}^{3}$ of a building requires $0.8 \mathrm{~m}^{3}$ of earthmoving and a consumption of diesel fuel of $0.104 \mathrm{~kg}$ (equivalent to $1.39 \mathrm{kWh}$ ). According to the different products and construction processes applied in the building, SOFIAS estimates the inert waste generated during the construction of the building.

\subsubsection{Use stage}

During the usage stage, SOFIAS quantifies the impact in relation to two phases: replacement (B4) and operational energy use (B6).

The replacement phase's impact represents the sum of environmental inputs associated with the environmental resource required to manufacture and replace materials and systems across the building's service life. Therefore, the database of Sofias contains information related to the Estimated Service Life of each of the materials and systems.

Table 4. Input and output data related to the the construction process stage of the building analysed to be entered into the SOFIAS tool.

\begin{tabular}{|l|c|l|c|}
\hline \multicolumn{2}{|c|}{ Earthmoving work (INPUT) } & \multicolumn{2}{c|}{ Constructive solutions and structural elements (OUTPUT) } \\
\hline Volume of excavation $\left(\mathrm{m}^{3}\right)$ & 19,157 & Water consumption $\left(\mathrm{m}^{3}\right)$ & 1,033 \\
\hline Inert waste generated $(\mathrm{t})$ & 342,488 & Electricity consumption $(\mathrm{kWh})$ & 57,925 \\
\hline Distance to the waste management system $(\mathrm{km})$ & 50 & Distance to the waste management system $(\mathrm{km})$ & 50 \\
\hline Diesel consumption $(\mathrm{kWh})$ & 33,287 & Diesel consumption $(\mathrm{kWh})$ & 59,164 \\
\cline { 3 - 5 } & & Waste generated $(\mathrm{t})$ & 724,133 \\
\cline { 2 - 5 }
\end{tabular}

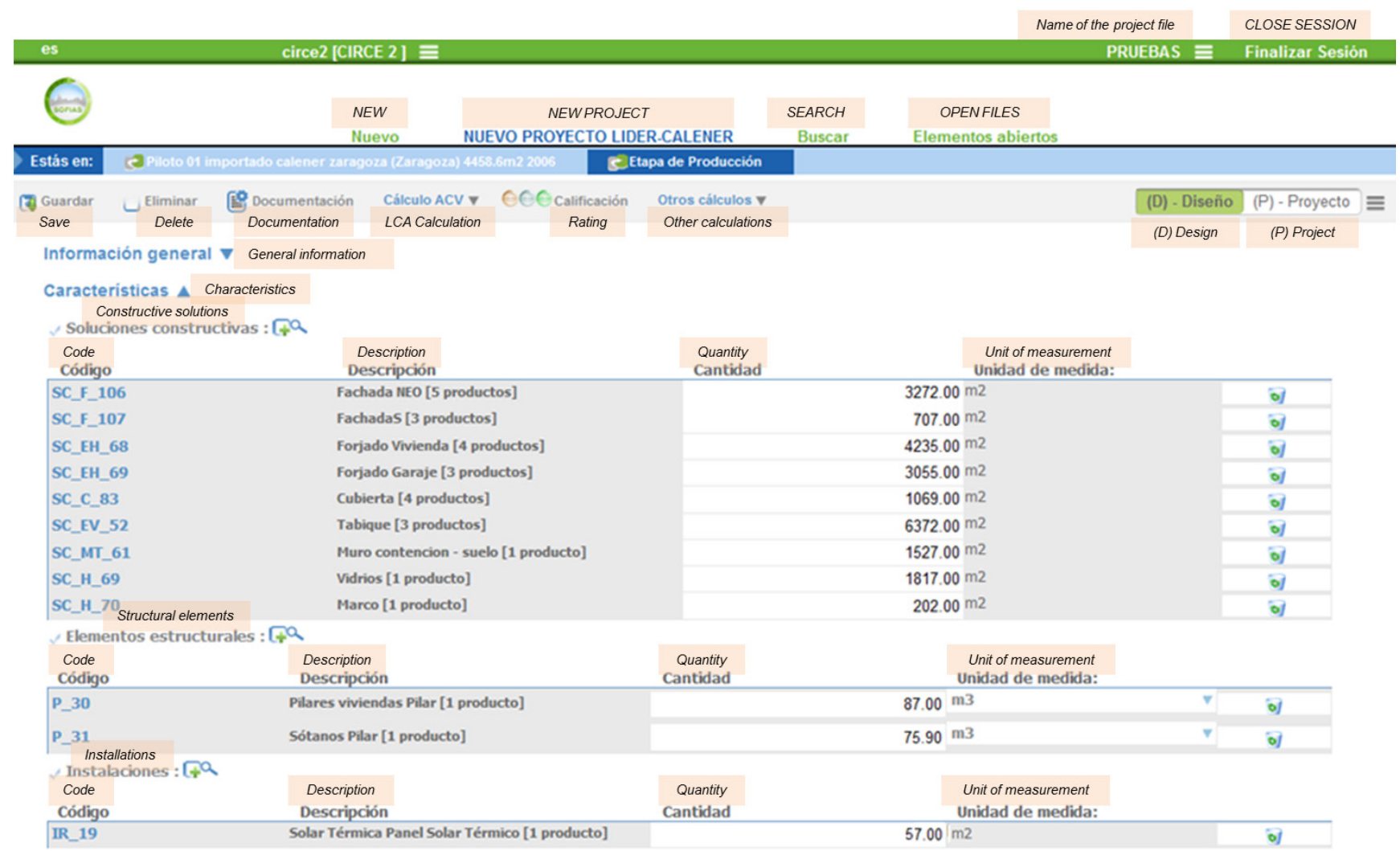

Figure 3. SOFIAS tool interface containing the main input data related to the product stage of the building analysed. 
In relation to the operational energy use phase, the energy consumption of the building has been obtained using the standardised tool Lider-Calener. As previously explained, it is possible to transfer all of the necessary data of the building from Lider-Calener to SOFIAS. In conjunction with the calculation of the energy efficiency rating of buildings (Rating $\mathrm{D}$ for this case study), Lider-Calener provides some results such as the final energy consumption for heating $(27.3 \mathrm{kWh} /$ $\mathrm{m}^{2}$ year), cooling (o $\mathrm{kWh} / \mathrm{m}^{2}$ year) and hot water $(7.6 \mathrm{kWh} /$ $\mathrm{m}^{2}$ year), calculated as the ratio of energy demand and the seasonal efficiency of facilities.

Based on the final energy consumption data and using conversion factor with life approach included in its database, the environmental impact of the use of the building, throughout the 50 years of useful life established by default, are calculated by SOFIAS.

\subsubsection{End of life stage}

As the deconstruction and demolition treatment that is going to be performed in the future with the building is generally not known, an end of life scenario, similar to the reference scenario, in which $100 \%$ of the materials of the building are transported to landfill is taken into account. Therefore, in the building analysed, 8,360.51 t of waste are transported for treatment in landfill.

\subsection{Discussion of the results}

The results produced by SOFIAS are grouped into 9 impact categories (see Table 5), showing the environmental impact caused by the building throughout its life cycle. These results can also be analysed globally or per $\mathrm{m}^{2}$ and year.

The results provided show different impact distributions between the different stages of the life cycle, according to each impact category. In the case of the GWP impact category, the majority of the impact generated by the building will occur in the use stage ( $72 \%$ ), followed by the production stage (23\%), where the transport ( $2 \%)$, construction process ( $2 \%$ ) and the end of life (1\%) stages have a lower impact.

The distribution percentages of the primary energy use between the different stages of the life cycle are similar to those of the carbon footprint. The use stage has the greatest de- mand for primary energy (69\%), followed by the production stage (24\%) and the construction stage (6\%). Due to the limits established for the analysis, the end of life stage is barely significant. It is possible to verify that the majority of the demand for primary power is from non-renewable sources, which entails $96.29 \%$ of the total primary power.

As shown in the Figure 4, the proposed rating system is a useful tool to detect the strengths and weaknesses of the analyzed building. In global terms, the analyzed building is close to the reference building, because it meets applicable national normative considered as reference. However, the selection of more sustainable materials in the building design involves a lower impact in the product stage. Moreover, the consideration of bioclimatic criteria in the building design and the highest standards of municipal regulations in comparison with the national legislation, involve an impact reduction in the use stage, due to the lower operational energy consumption needed to maintain the thermal comfort. Finally, the impact of the construction process stage and end-of-life stage is very similar in both buildings, because both constructive and deconstructive systems considered for the building are conventional.

In order to calculate the rating, different linear equations are generated by the SOFIAS tool for each life cycle stage of the building. Then the numerical rating for each stage is calculated using the corresponding linear equation. Finally the total rating is calculated using a global linear equation, where the reference point is just the addition of the equivalent $\mathrm{CO}_{2}$ emissions reference values for each life cycle stage. Therefore no weighting factors are considered for the total rating calculation.

Analysing these results in greater detail, it is observed that the main reduction in $\mathrm{CO}_{2}$ gas emissions comes from the selection of the materials that comprise the building studied. These constructive solutions present fewer $\mathrm{CO}_{2}$ emissions because the building incorporates insulation based on natural cork, and light clay brick system that does not incorporate thermal insulation for the south facade of the building. Table 6 shows a comparison of the emissions associated with the study and reference buildings.

Another of the notable differences lies in the interior vertical partitions where the emissions per $\mathrm{m}^{2}$ are lower, as a light partition wall is not used. In the case of the wall in contact

Table 5. Results provided by SOFIAS related to environmental impact indicators and consumptions of resources per $\mathrm{m}^{2}$ and year. Life cycle stages acronyms are defined according to EN 15978 nomenclatures.

\begin{tabular}{|c|c|c|c|c|c|c|}
\hline \multirow[b]{2}{*}{ Impact category } & \multirow{2}{*}{$\begin{array}{c}\text { Product Stage } \\
\text { A1-3 }\end{array}$} & \multicolumn{2}{|c|}{ Construction process stage } & \multicolumn{2}{|c|}{ Use stage } & \multirow{2}{*}{$\begin{array}{c}\text { End of life Stage } \\
\mathrm{C2-3}\end{array}$} \\
\hline & & A4 & A5 & B4 & B6 & \\
\hline GWP & $7 \cdot 3 \mathrm{E}+\mathrm{Oo}$ & $5.8 \mathrm{E}-\mathrm{O} 1$ & $4.7 \mathrm{E}-\mathrm{O} 1$ & $2.5 \mathrm{E}-\mathrm{O} 2$ & $2.3 \mathrm{E}+\mathrm{O} 1$ & $6.2 \mathrm{E}-\mathrm{O} 1$ \\
\hline ODP & $4.1 \mathrm{E}-\mathrm{O} 5$ & $1.4 \mathrm{E}-12$ & $1.4 \mathrm{E}-10$ & $2.6 \mathrm{E}-12$ & $2.4 \mathrm{E}-11$ & $5.1 \mathrm{E}-\mathrm{O} 1$ \\
\hline $\mathbf{A P}$ & $6.5 \mathrm{E}-\mathrm{O} 1$ & $3.9 \mathrm{E}-\mathrm{O} 3$ & $1.7 \mathrm{E}-\mathrm{O} 3$ & $2.2 \mathrm{E}-\mathrm{O} 4$ & $1.9 \mathrm{E}-01$ & $5.1 \mathrm{E}-\mathrm{O} 1$ \\
\hline $\mathbf{E P}$ & $2.1 \mathrm{E}-\mathrm{O} 1$ & $9.6 \mathrm{E}-\mathrm{O} 4$ & $1.4 \mathrm{E}-\mathrm{O} 4$ & $8.7 \mathrm{E}-06$ & $1.1 \mathrm{E}-\mathrm{O} 2$ & $5.1 \mathrm{E}-\mathrm{O} 1$ \\
\hline POCP & $3.6 \mathrm{E}-\mathrm{O} 2$ & $1.6 \mathrm{E}-\mathrm{O} 3$ & $1.8 \mathrm{E}-\mathrm{O} 4$ & $1.1 \mathrm{E}-\mathrm{O} 5$ & $9.1 \mathrm{E}-\mathrm{O} 3$ & $5.1 \mathrm{E}-\mathrm{O} 1$ \\
\hline ADP-elements & $8.6 \mathrm{E}-01$ & $2.7 \mathrm{E}-08$ & $1.1 \mathrm{E}-\mathrm{O} 7$ & $3.4 \mathrm{E}-06$ & $5.5 \mathrm{E}-\mathrm{O} 8$ & $5.08 \mathrm{E}-01$ \\
\hline ADP-fossil fuels & $5 \cdot 9 \mathrm{E}+\mathrm{O} 1$ & $7.9 \mathrm{E}+\mathrm{Oo}$ & $6.4 \mathrm{E}+\mathrm{OO}$ & $2.7 \mathrm{E}-\mathrm{O} 1$ & $2.2 \mathrm{E}+\mathrm{O} 2$ & $2.1 \mathrm{E}+\mathrm{OO}$ \\
\hline PE & $7 \cdot 5 \mathrm{E}+\mathrm{O} 1$ & $8.5 \mathrm{E}+\mathrm{Oo}$ & $1.1 \mathrm{E}+\mathrm{O} 1$ & $4.1 \mathrm{E}-\mathrm{O} 1$ & $2.2 \mathrm{E}+\mathrm{O} 2$ & $2.2 \mathrm{E}+\mathrm{OO}$ \\
\hline NRPE & $6.7 \mathrm{E}+\mathrm{O} 1$ & $7.9 \mathrm{E}+\mathrm{OO}$ & $8.4 \mathrm{E}+\mathrm{OO}$ & $3.2 \mathrm{E}-\mathrm{O} 1$ & $2.2 \mathrm{E}+\mathrm{O} 2$ & $2.1 \mathrm{E}+\mathrm{OO}$ \\
\hline
\end{tabular}




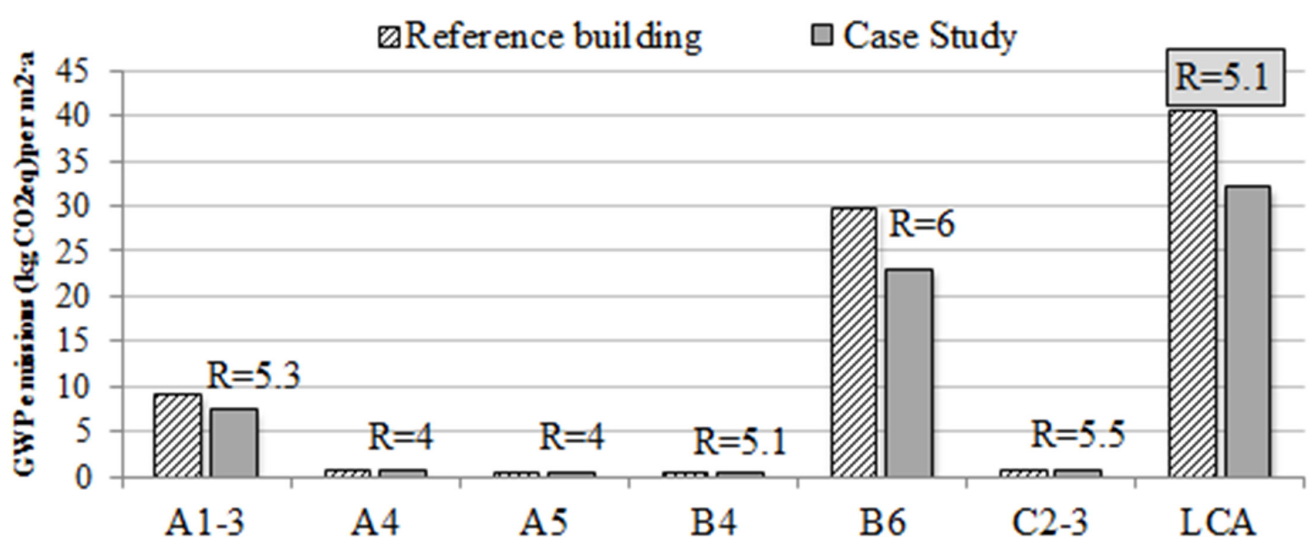

Figure 4. GWP emissions differences between the reference building and the case study. The "R" value determinate the rating puntuation of each Life Cycle Stage.

Table 6. Results comparison on the constructive solutions provided by the tool and reference emissions.

\begin{tabular}{|c|c|c|}
\hline & $\begin{array}{l}\text { Reference Building }\left(^{*}\right) \\
\text { kg. } \mathrm{CO}_{2} \text { eq. } /\left(\mathrm{m}^{2} \cdot \mathbf{a}\right)\end{array}$ & $\begin{array}{l}\text { Building Analysed } \\
\mathrm{kg} \cdot \mathrm{CO}_{2} \text { eq. } /\left(\mathrm{m}^{2} \cdot \mathbf{a}\right)\end{array}$ \\
\hline \multirow{2}{*}{ Façade } & \multirow{2}{*}{96.54} & 51.64 (North, East and West Façade \\
\hline & & 26.36 (South Façade) \\
\hline Roof & 188.7 & 143.4 \\
\hline Internal foundation & 106.2 & 84.06 \\
\hline Internal wall & 13.4 & 34.04 \\
\hline Grounded wall & 143.9 & 109.02 \\
\hline Window glass & 0.03991 & 0.030 \\
\hline
\end{tabular}

$(*)=$ Reference building for winter climatic severity "D" according to the Spanish regulations

with the ground, as it is a basement shared with other adjacent blocks in the same urbanisation, this means the amount of perimeter containment wall necessary to create the basement can be reduced.

\section{CONCLUSIONS}

SOFIAS aims at helping building professionals to reduce the environmental footprint of construction projects applying a life cycle approach and, therefore, avoiding impact shifting amongst impact categories or life cycle stages. However, a fully-fledge application of the Life Cycle Assessment (LCA) methodology of buildings faces important challenges due to the remarkably huge scope of this kind of analysis and, even more important, the lack of time and resources and difficult access to the required data recognized by the building professionals.-

Environmental Product Declarations are becoming an important source of data for conducting LCA studies of buildings. Nowadays hundreds of EPDs for different building products are available and can be integrated in LCA studies. Environmental impact information from cradle to gate of 364 products has been included in SOFIAS' database, classified according to the Spanish Construction Elements Catalogue.

To computerize environmental products information from EPDs and to integrate this information in LCA tools (such as SOFIAS) will foster its development, as well as contribute to increase the employment of these declarations in building assessment and the calculation of "Environmental Building Declarations" as demonstrated by SOFIAS.
The rating system integrated in the tool is applied on just one indicator, the equivalent emissions of carbon dioxide, due to its current relevance today.

The numerical and visual rating proposed in this paper allows an easy understanding of the environmental assessment results by the different stakeholders of the building sector. This also promotes the design of low environmental impact buildings and facilitates the consideration of environmental indicators which can be easily understood by the building users or buyers.

The main new feature of the SOFIAS project is that it provides the construction sector in Spain with a new instrument, that did not exist until now, to improve the design of buildings using an environmental and energy assessment of the buildings including a quantification of the embodied energy throughout the life cycle of the buildings: from the manufacture of their components and their construction, to the stages of use and maintenance, and their restoration or end of life. Therefore, the SOFIAS tool enables us to quantitatively evaluate improvements in the design of buildings, both new and existing, with the aim of reducing their energy, environmental and economic costs, bringing building design closer to a new standard of "Life Cycle Zero Emission Buildings".

\section{ACKNOWLEDGEMENTS}

This paper has been developed from the results obtained in the frameworks of SOFIAS (Ref. number IPT-2011-0948380000) project co financed by the Spanish Ministry of Economy and Competitiveness. 


\section{REFERENCES}

(1) European Commission. (2014). Resource efficiency opportunities in the building sector. COM 445 final. Brussels, 1.7.2014.

(2) AENOR. (2006). UNE-EN ISO 14040:2006. Environmental management - Life cycle assessment - Principles and framework.

(3) AENOR. (2006). UNE-EN ISO 14044:2006. Environmental management - Life cycle assessment - Requirements and guidelines.

(4) Guinée, J. B., Gorrée, M., Heijungs, R., Huppes, G., Kleijn, R., de Koning, A., van Oers, L., Sleeswijk, A. W., Suh, S., de Haes H. A. U., de Bruijn, H., van Duin, R., Huijbregts, M. A. J. (2001). Life cycle assessment - An operational guide to the ISO standards. Centre for Environmental Studies (CML), Leiden University.

(5) Goedkoop, M., Spriensma, R. (2001). The Eco-indicator 99. A damage oriented method for life cycle assessment. Amersfoot, The Netherlands: Pre-consultants.

(6) AENOR. (2012). UNE-EN 15978:2011. Sustainability of construction works-Assessment of environmental performance of buildings-Calculation method.

(7) CEN TC 350. European Committee for Standardization, Technical Committees. Sustainability of construction works. Available online: http://portailgroupe.afnor.fr/public_espacenormalisation/centc350/index.html.

(8) SimaPro. Amersford, Netherlands: Pré Consultants bv. Available online: http://www.pre-sustainability.com/simapro.

(9) GaBi. Product sustainability performance solutions by PE Europe GmbH and IKP University of Stuttgart. (2014).

(10) Umberto. Available online: http://www.umberto.de/en/ (accessed on May 2015).

(11) Assefaa, G., Glaumann, M., Malmqvist, T., Eriksson, O. (2010). Quality versus impact: Comparing the environmental efficiency of building properties using the EcoEffect tool. Building and Environment, 45(5): 1095-1103.

(12) Zeiler, W., Pelzer, R., Maassen, W. (2013). LCA in the Netherlands: A case study. Smart Innovation. Systems and Technologies, 22: 649-658.

(13) Kohler, N., Wagner, A., Luetzkendorf, T., König, H. (2005). Life cycle assessment of passive buildings with LEGEP $\mathbb{R}$ - a LCA tool from Germany, https://www.researchgate.net/publication/228467636_LIFE_CYCLE_ASSESSMENT_ OF_PASSIVE_BUILDINGS_WITH_LEGEPR-A_LCA-TOOL_FROM_GERMANY.

(14) Yu, C.-J., Kang, J. (2009). Environmental impact of acoustic materials in residential buildings. Building and Environment, 44(10): 2166-2175.

(15) Rajagopalan, N., Bilec, M. M., Landis, A. E. (2012). Life cycle assessment evaluation of green product labeling systems for residential construction. International Journal of Life Cycle Assessment, 17(6): 753-763.

(16) Stek, E., Delong, D., McDonnell, T., Rodriguez, J. Life cycle assessment using ATHENA® impact estimator for buildings: A case study. Structures Congress 2011 - Proceedings of the 2011 Structures Congress, pp. 483-494.

(17) Rossi, B., Marique, A.-F., Glaumann, M., Reiter, S. (2012). Life-cycle assessment of residential buildings in three different European locations, basic tool. Building and Environment, 51: 395-401.

(18) Tool LTE OGIP; Version 5.o; Build-Number 2092; 2005/12/12. Available online: http://eplca.jrc.ec.europa.eu/ResourceDirectory/tool.vm?tid=234.

(19) Klunder, G. (2004). The search for the most eco-efficient strategies for sustainable housing construction; Dutch lessons. Journal of Housing and the Built Environment, 19(1): 111-126.

(20) Available online: http://www.elodie-cstb.fr/

(21) Gustavsson, L., Joelsson, A. (2010). Life cycle primary energy analysis of residential buildings. Energy and Buildings, 42: $210-220$.

(22) Hernández, P., Kenny, P. (2010). From net energy to zero energy buildings: defining life cycle zero energy buildings (LCZEB). Energy and Buildings, 42: 815-821.

(23) Ortiz-Rodríguez, O., Castells, F., Sonnemann, G. (2010). Life cycle assessment of two dwellings: One in Spain, a developed country, and one in Colombia, a country under development. Science of the Total Environment, 408: 2435 -2443.

(24) Dodoo, A., Gustavsson, L., Sathre, R. (2010). Life cycle primary energy implication of retrofitting a wood-framed apartment building to passive house standard. Resources, Conservation and Recycling, 54: 1152-1160.

(25) Malmqvist, T., Galumann, M., Scarpellini, S., Zabalza, I., Aranada, A., Llera, E., Diaz, S. (2011). Life cycle assessment in buildings: The ENSLIC simplified method and guidelines. Energy, 36: 1900-1907.

(26) Rossi, B., Marique, A. F., Glaumann, M., Reiter, S. (2012). Life-cycle assessment of residential buildings in three different European locations, basic tool. Building and Environment, 51: 395-401.

(27) Ramesh, T., Prakash, R., Shukla, K. K. (2012). Life cycle energy analysis of a residential building with different envelopes and climates in Indian context. Applied Energy, 89: 193-202.

(28) Stephan, A., Crawford, R. H., Myttenaere, K. A. (2013). Comprehensive assessment of the life cycle energy demand of passive houses. Applied Energy, 112: 23-34.

(29) Mosteiro-Romero, M., Krogmann, U., Wallbaum, H., Ostermeyer, Y., Senick, J. S., Andrews, C. J. (2014). Relative importance of electricity sources and construction practices in residential buildings: A Swiss-US comparison of energy related life-cycle impacts. Energy and Buildings, 68: 620-631.

(30) Dodoo, A., Gustavsson, L., Sathre, R. (2014). Lifecycle primary energy analysis of low-energy timber building systems for multi-storey residential buildings. Energy and Buildings, 81: 84-97.

(31) Wadel, G., López, F., Sagrera, A., Prieto, J. (2011). Refurbishment considering environmental bimpact reduction targets: a test case for a multiple-family dwelling in the area of Playa de Palma, Mallorca. Informes de la Construcción, 63: 89-102.

(32) Ministry of Housing. Royal Decree 235/2013, of 5th April, establishing the basic procedure for certification of energy buildings efficiency. BOE, 89, 13th April 2013. 
(33) Emara, T., Ciroth, A. (2014). The database ÖKOBAU.DAT in openLCA and SimaPro. Green Delta.

(34) Mabe, L., Gazulla, C. (2012). Use of Environmental Product Declarations (EPD) in LCA studies of buildings. Proceedings of the 1st International Conference on Building Sustainability Assessment (BSA). Porto.

(35) Ministry of Housing, CSIC Eduardo Torroja Institute for Construction Science. Catalog of Constructive Elements. Available online: http://www.codigotecnico.org/images/stories/pdf/aplicaciones/nCatalog_infoEConstr/CAT-EC-vo6.3_ marzo_10.pdf.

(36) Available online: http://www.opendap.es/app.php/

(37) Ministry of Housing. (2013). Order FOM/1635/2013, of $10^{\text {th }}$ September. CTE-DB-HE Technical Building Code - Energy saving Document updated. BOE, 219, 12 $2^{\text {th }}$ September 2013.

(38) Kellenberger, D., Althaus, H. J., Jungbluth, N., Lehmann, M., Thalmann, P., (2007). Life Cycle Inventories of Building Products: Final report ecoinvent Data, 7. EMPA Dübendorf, Swiss Centre for Life Cycle Inventories, Dübendorf, Switzerland

(39) Ministry of Housing. Royal Decree 314/2006, of 17 th March, approving The Spanish Technical Building Code. BOE, 74, 28th March 2006

(40) SOFIAS software. Available online: https://repcon.sofiasproject.org/login.html (accessed on April 2015).

(41) AENOR. (2012). UNE-EN 15804:2012. Sustainability of construction works - Environmental product declarations. Core rules for the product category of construction products. 